\title{
Application of Six Sigma Methodology in Glazing and Printing Processes: The Case of Lanka Wall Tiles PLC
}

\author{
D M A Kulasooriya and K K A Nihal Kumarasinghe
}

\begin{abstract}
Six Sigma is a data-driven process of thinking to create new knowledge and skills for business process improvement. It is a buzz word in the business community today as Six Sigma thinking has gained widespread popularity as a part of business process improvement methodology. This paper presents the results of applying Six Sigma methodology at Lanka Wall Tiles PLC in the areas of glazing and printing operations. The company in its process reengineering project identified glazing and printing operations as the main processes in which defects occur regularly. In order to address the issue of production defects a five-step DMAIC framework, viz. Define, Measure, Analyze, Improve and Control, was applied. In the define stage, the size of the problem was gauged after mapping the process by means of the SIPOC (Supplier, Input, Process, Outputs, Customer) model. In the measurement and data analysis stages, a set of carefully chosen statistical methods and problem solving techniques of Six Sigma system were applied to uncover the sources of variations (SOV). Data was collected from both the past records of production and by observation of the process for a period of 21 days. Data analysis was done using tools and techniques such as quality function deployment (QFD), control charts, cross tabulation, cause and effect diagrams and Pareto charts. A detailed analysis of the data revealed the major sources of variations for which homegrown solutions were found and implemented by the project team at the improvement stage. A cautious application of DMAIC over a period of two months resulted in a gradual and steady reduction of defects by a significant 3.3 percent giving rise to savings of approximately LKR 3.36 million per month for the company. It further revealed that the methodical and systematic application of the Six Sigma system using the thinking process of DMAIC enabled the team to identify sources of variations that had been undetected for a long period of time. The success of the experiment paves the way for further studies as well as the application of Six Sigma methodology in the manufacturing environments of all production units of the company.
\end{abstract}

Keywords: CTQ, DMAIC, QFD, SIPOC, Six Sigma, Sources of Variation (SOV)

D M A Kulasooriya, $\boldsymbol{P h D}$ is a Director of NIBM and Director, Academic Affairs, NSBM. E-mail: dmak@nibm.lk K K A Nihal Kumarasinghe is the Factory Manager, Lanka Wall Tiles PLC. 


\section{NSBM Journal of Management}

Vol. 1, No. 2, July-December, 2015

\section{Introduction}

Six Sigma is a quality improvement methodology for developing and delivering virtually perfect products and services and has gained widespread popularity in industry as a business process improvement approach. Six Sigma is defined as '.. a process of business operations which makes it possible for companies to rigorously make better their basic formation...' (Harry \&Schroeder 2000, p. vii). The concept of Six Sigma originated at Motorola Inc. in the USA in 1985 aimed at reducing the number of defects in operational processes. Further, it is a statistical measure of the performance of a process which implicates a goal of reducing the number of defects to 3.4 defects per million opportunities (DPMO). Six Sigma adopts a structured and systematic approach to reduce variations of a process and thereby the number of defects. Following the successful implementation of Six Sigma methodology by Motorola, a large number of companies implemented it worldwide with many success stories that are documented in numerous academic papers. Given the widespread acceptance of Six Sigma in both manufacturing and service industries it is assumed that the academia should continue to study Six Sigma in greater depth in order to understand inbuilt methodological and deployment issues, orientation of management as well as critical success factors.

The objective of this paper, which takes the form of a case study, is to present the results of applying Six Sigma methodology at Lanka Wall Tiles PLC, Sri Lanka, where the process deviations in the glazing and printing operations resulted in a higher rate of defective outputs. It is hoped that this success story would motivate companies engaged in similar operations to apply Six Sigma methodology in their organizations. Further, it is likely to encourage academia to replicate the study in other processes and service industries with a view to broadbasing the application of this methodology.

The paper is organized as follows: At the outset, a brief introduction to Lanka Wall Tiles PLC, the empirical site for the case study, is given. This is followed by a reflection on the Six Sigma methodology and the DMAIC framework. The application of the Six Sigma methodology in the glazing and printing processes via define, measure, analyze, improve and control stages is narrated followed by a documentation of results achieved and the learning points. The paper also highlights some important areas for further studies.

\section{Empirical Site: Lanka Wall Tiles PLC}

Lanka Wall Tiles PLC (LWPLC) is in the business of production and distribution of ceramic Wall Tiles in Sri Lanka. The company offers a wide range of tiles of various colours, textures, and sizes, including distinctive products such as trim tiles, decorated tiles, handmade and 
hand-painted tiles. The product lines also include floor tiles, cartons and paper sacks for packing and tile grout and the mortar. LWPLC has been manufacturing and exporting high quality ceramic tiles for over twenty years from this factory's Plant A. During the last financial year (2014/15), LWPLC contributed to its employees LKR 349 million as remuneration and LKR 358 million to the state as taxes and LKR 702 million as foreign exchange earnings through exports. Further, LWPLC has provided 500 direct employment and more than 1000 as indirect employment. Moreover, LWPLC has brought state of the art technology to the development of the industry which includes: LGV (Laser Guided Vehicle) to replace manoperated forklifts and the latest Digital Printing Technology to replace traditional screen printing, etc.

Having been in the business for more than twenty years, LWPLC has emerged as the market leader and premier ceramic wall tile manufacturer in Sri Lanka. LWPLC is now a major contender in highly competitive markets, supplying quality Wall Tiles to up-market consumers both locally and internationally. The main manufacturing facility for ceramic Wall Tiles is located in Meepe, Padukka, on the outskirts of Colombo where two large plants A and $\mathrm{B}$ together produce tiles of 7,500 sq. per day. There is a production capacity of 4,500 sq. per day in Plant A (established in 1996) and a production capacity of 3,000 sq. per day in Plant B (established in 2011). The capacity details for plant A, where the Six Sigma methodology was conducted is given in Table 1 .

Table 1: Capacities of Plant A

\begin{tabular}{lcc}
\hline Type (size in mm) & SKU (No. of Designs) & Product Mix (\%) \\
\hline $200 \times 200$ & 38 & 22.91 \\
$200 \times 300$ & 82 & 63.07 \\
$300 \times 300$ & 30 & 14.02 \\
Total & $\mathbf{1 5 0}$ & $\mathbf{1 0 0}$ \\
\hline
\end{tabular}

Source: Lanka Wall Tiles PLC

\section{Six Sigma Methodology}

Blakeslee (1999) defines Six Sigma as a data-driven approach for analyzing the root causes of business problems and solving them while Hahn, Doganaksoy \& Hoerl, R (2000), recognize it as a disciplined and statistically based approach for improving products and process quality. In initiating Six Sigma, Motorola Inc. set itself the goal of achieving 99.9997 percent defect-free production or, in other words, restricting defects to 3.4 per million items 


\section{NSBM Journal of Management}

Vol. 1, No. 2, July-December, 2015

produced per million opportunities (DPMO). Reflection on monetary gains is an essential component of Six Sigma projects as its ultimate purpose is to achieve savings by reducing the costs associated with defective production. Thus, Six Sigma applications are initiated after a thorough assessment of the positive impact of the project on the bottom line of the organizations, which kindles the interest of the management to embark on them (Brady \& Allen 2006).

The literature on Six Sigma could be broadly classified into two categories: Methodologyand Management-related Approaches to Six Sigma Implementation. Brady and Allen (2006), while noting a tendency towards methodology- related approaches by writers, observe that Six Sigma implementers depend on simplified versions of statistical methods, and in the process, disregard the in-built theoretical aspects. In order to effect systematic implementation, Six Sigma implementers also employ various quality management tools and techniques with a view to finding root causes and effecting process improvement (Linderman et al. 2003). They include the Ishikawa diagram or fish bone diagram (cause and effect diagram) to find the root causes of the problem, Pareto analysis to prioritize problems, histograms to check the distribution of a process, and control charts to track the trends in a process. Zu, Fredendall and Douglas (2008) emphasize that quality management practices can be used in combination with Six Sigma to improve process performance.

The second type of literature which propagates the importance of right management orientation in Six Sigma implementation emphasizes factors such as the role of leadership, teamwork, and social dynamics. Two common management approaches in use are the define-measureanalyze-improve-control (DMAIC) framework that is used in current process improvement and the define-measure-analyze-design-verify (DMADV) framework used in product/ service design improvement (Linderman et al. 2003). It is interesting to note that both these approaches have their roots in the plan-do-check-act (PDCA) cycle of process improvement which can be traced to the pioneering work in the mid-20th century by quality guru Dr. Edward Deming. The application of these frameworks provides a structured approach to the execution of Six Sigma projects which facilitates teamwork and promotes learning and knowledge acquisition within teams (Choo, Linderman, \& Schroeder 2007).

Another facet of management-related literature is the study of critical success factors (CSF), which are imperative for the successful implementation of Six Sigma projects. Chakrabarty and Tan (2007), Coronado and Antony (2002) and Goh (2002) are of the view that topmanagement support and commitment are critical for the success of Six Sigma projects as they require allocation of resources and deployment of cross-functional teams. Further, 
they emphasize that implementation of Six Sigma needs improvement specialists, typically tagged as champions, viz. master black belts, black belts, and green belts depending on their expertise and the degree of involvement in the projects. Typically, master black belts serve as mentors, black belts as project leaders and green belts as problem solvers (Barney 2002, Schroeder et al. 2008).

\section{DMAIC Method}

The literature on Six Sigma by many writers including Chalapathi (2005 a, 2005 b, 2000 c) and Sung Park (2003) suggest that the DMAIC (define-measure-analyze-improve and control) framework with its in-built robust and structured approach could be a major success factor in ensuring better results in the Six Sigma implementation process. An outline of the scheme of work associated with the five phases of the DMAIC framework is given in the next section.

The Define stage commences with an initial understanding of the process in which major issues are observed. This is followed by making decisions on the scope and boundaries of the process where the real problems exist. This has to be substantiated with quantitative evidence gathered from the areas in question. Next, the impact on the business that will accrue from implementing Six Sigma has to be estimated followed by preparing a well-defined statement of objectives and goals. This stage also calls for mapping the processes based on the total value chain consisting of suppliers, inputs, process, outputs and customers (SIPOC) followed by the identification of critical areas. Quality Function Deployment (QFD) can be deployed for this purpose. QFD is a tool/structured approach for relating the voice of the customer to the technical requirements of the process designed to identify the critical to quality (CTQ) from the voice of customers (VOC) and critical to process (CTP), critical to inputs (CTI) and critical to suppliers (CTS). Alongside, standardization of processes the appointment of a team for executing the project also takes place in this stage.

The Measurement stage presents the map of data collection. After identifying critical areas of the problem in the process, the measurement stage is executed by collecting data on critical areas of the operations. In the Measurement stage data is collected with the use of a planning sheet which identifies the critical process steps, modes of identifying defects, operational definitions, data types, method of stratification as well as the sample size. In addition, the means of process improvement are conceptualized by identifying the relevant variables. 


\section{NSBM Journal of Management}

Vol. 1, No. 2, July-December, 2015

In the Analysis stage data and process analysis is carried out of the sources of variations and causes. Defects are identified visually and recorded on a daily basis and the analysis is carried out by applying techniques such as Pareto analysis, Control Charts. This is followed by carrying out a cause and effect relationship analysis using the Ishikawa diagram.

The Improvement stage is intended to develop alternative solutions for the removal of causes identified in the analysis stage. It is important to note that ninety percent of the exercise is complete once the causes are identified and validated. Further, it is to be noted that improvement begins from the first (define) stage and continues at varying successive stages up to the control stage.

The final stage, i.e. Control, involves standardizing the process/es which is the key to the stabilization and sustainability the process. Further, preparing new Standard Operating Procedures (SOPs) is followed by the documentation of the new process. Also, monitoring has to be carried out on a regular basis and in accordance with a pre-determined schedule using control measures such as statistical process control methods (SPCs).

\section{The Six Sigma Project - Lanka Wall Tiles PLC}

The following sections present the sequential implementation of the cycle of DMAIC in the glazing and printing process of the tile production company. The period of the study was between October 24 to November 13, 2014 at the location of LWPLC Plant A at Meepe, Padukka. Twenty pieces were taken from the defective tiles collected at the sorting line every one hour, for 21 days consecutively. These samples were analyzed for glazing- related defects and they were tabulated under each category of defects in a data analysis sheet for further analysis.

The team consisted of Head of Finance (Champion), Factory Manager (Team Leader) and Assistant Factory Manager, Assistant Production Manager, Production Executive (Glaze Preparation), Production Executive (Glazing), and Assistant Quality Assurance Executive as team members. The complete project was implemented under the direct leadership and supervision of the Factory Manager (Team Leader), which is a partial fulfillment of the Six Sigma Black Belt Certification Programme conducted by the National Institute of Business Management (NIBM), Sri Lanka, under the guidance of the first author of this paper. 


\section{Define Stage}

The define stage specifies the background, scope, financial benefits, objectives, process mapping as well as application of Quality Function Deployment.

\section{Background}

Lanka Wall Tiles Ltd. currently enjoys a share of 45 percent in an extremely competitive local market. This is in spite of the glut of low-priced imports in the local markets, the policy of the government being to impose the minimum protective tariff barriers against anti-dumping. A recent market analysis revealed that the cheapest imported products are of sizes of $200 \times 200 \mathrm{~mm}, 200 \times 300 \mathrm{~mm}$ and $300 \times 300 \mathrm{~mm}$, which the company produces in Plant A. Management was under severe pressure to reduce the manufacturing cost of the ranges produced in plant A in order to be competitive in a highly dumped local market. Although various steps had already been taken to reduce the cost, the top management was of the view that there was enough room for further improvement by stabilizing the production process.

\section{Scope}

The study was confined to the production process in order to measure quality levels and to identify sources of variation. At the outset, it was revealed that the defective rate in Plant A stands at 8.78 percent (refer Table 3). Further, it was identified that 4.42 percent of defectives originated in the glazing and printing operations (refer Table 4). Hence, the study focused on variations in good output coming out of the glazing and printing operations in Plant A.

Table 2: Plant A-Final Product Sorting Summary, May to October, 2014

\begin{tabular}{lcccccccc}
\hline Month & & May & June & July & Aug. & Sept. & Oct. & Total \\
Total Defects & $\mathrm{m}^{2}$ & 11,141 & 11,936 & 11,556 & 10,581 & 9,902 & 13,063 & 68,179 \\
& $\%$ & 8.71 & 10.23 & 8.83 & 7.24 & 7.56 & 10.59 & 8.78 \\
\hline
\end{tabular}


NSBM Journal of Management

Vol. 1, No. 2, July-December, 2015

Table 3: Plant A-Final Product Sorting Summary, Glazing Section, May to October, 2014

Defect Type (Glazing Line related)

Defect Pieces

(Per month

average.)

Bald edge

19,659

Glaze bead

5,790

Glazed crack

5,741

Glaze scar 1

4,963

Print defect

4,893

Dent

3,291

Glaze scar 2

2,755

Boss G

2,522

Engobe hump

2,201

Hole

1,961

Colour spot

1,639

Spit out

1,614

Pin Hole

1,414

Glaze line

Wave

Edge hole

(A) Glazing line defects (reject pieces)

60,530

(B) Total reject pieces

120,039

(C) Glazing line related rejects $(\mathrm{A} / \mathrm{B}) \times 100$

$50.43 \%$

Percentage of glazing-related rejects from total production (Considering

$4.42 \%$ the average of 6 months)

A further analysis of types of defects in the month of October, 2014 showed that bald edge, glaze bead, glazed crack, print defect, and glaze scar -1 occupy the first four slots of defects

In order to understand the operations of glazing and printing, a process map of it was drawn, which is depicted in Figure 1. Thus, in view of the above results the glazing and printing section in the process of glaze application was selected as the scope. 
Figure 1: Project Area: Glazing \& Printing Process

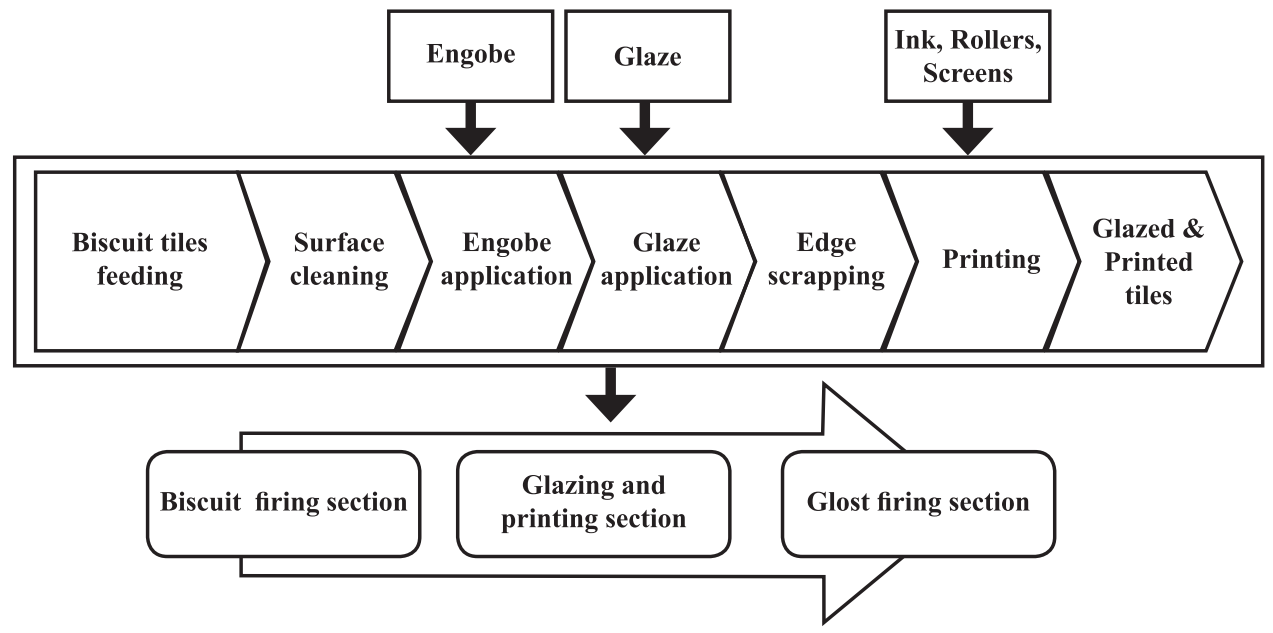

\section{Description of Terms}

Biscuit Tile: A fired tile which represents the base input for the final product

Engobe: A glass liquid layer applied on biscuit tiles

Glaze: A glass liquid layer applied on the engobe applied tiles, which produces the hard non-porous shining surface (matt or gloss) after firing.

In this process the input material is biscuit tiles while the output is glazed and printed tiles. During this process, the tiles are subjected to the fuctions, viz. surface cleaning, engobe application, glaze application, edge scraping and printing. Then the glazed tiles are transferred to the glost firing in the kiln.

\section{Impact on the Business}

The financial benefits could be counted as cash savings, improved customer satisfaction and increased market share in the long-run. The formula for cash savings is given in Figure 2. 
NSBM Journal of Management

Vol. 1, No. 2, July-December, 2015

Figure 2: Computation of Cash Savings

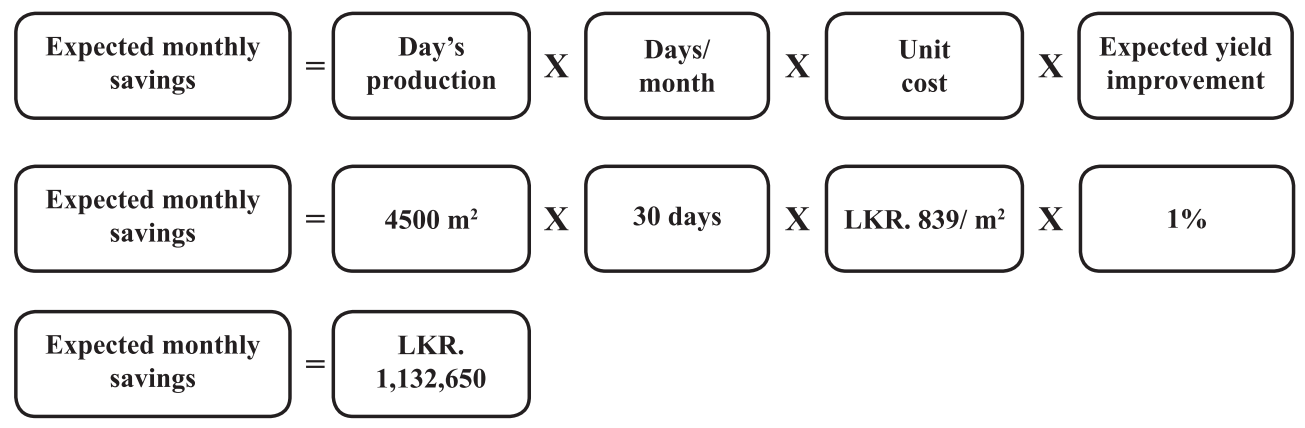

\section{Project Objectives}

The objective of the project was to reduce defectives by applying Six Sigma in the glazing and printing section at Lanka Wall Tiles PLC, which is a large-scale manufacturing facility in Sri Lanka. The goal of the proposed study was to reduce the defect rate of the output from the glazing and printing section by at least $3 \%$. This was expected to be achieved through the following steps:

i. Identifying opportunities where improvements are possible;

ii. Identifying the sources of variation leading to defectives; and

iii. Recommending and adopting steps to remove the sources of variation.

\section{Process Mapping}

Chart 1 depicts the process mapping of the process under consideration, biscuit tiles feeding to glazed and printed tile based on SIPOC. Once the process mapping is completed it is necessary to identify critical areas of the process where the focus is on producing better results. In order to identify opportunities for improvement and critical areas the Quality Deployment Function was deployed as depicted in Chart 2. 
Application of Six Sigma Methodology in Glazing and Printing Processes:

The Case of Lanka Wall Tiles PLC

Chart 1: SIPOC Model - Biscuit Firing Process

\begin{tabular}{|c|c|c|c|c|}
\hline Suppliers & Inputs & Process & Output & Customers \\
\hline $\begin{array}{l}\text { Biscuit Kiln } \\
\text { Section }\end{array}$ & Biscuit Tiles & $\begin{array}{l}\text { Biscuit tiles } \\
\text { feeding } \\
\text { (Good } \\
\text { biscuittiles) }\end{array}$ & Rejected Biscuits & $\begin{array}{l}\text { Crushing section } \\
\text { for recycling }\end{array}$ \\
\hline $\begin{array}{l}\text { Quality } \\
\text { Assurance } \\
\text { Department }\end{array}$ & $\begin{array}{l}\text { QC Instruction } \\
\text { Sheet }\end{array}$ & Inline - Checking & & \\
\hline $\begin{array}{l}\text { Glaze and Engobe } \\
\text { preparation } \\
\text { section }\end{array}$ & Engobe & $\begin{array}{l}\text { Engobe } \\
\text { application }\end{array}$ & Waste Engobe & $\begin{array}{l}\text { Effluent } \\
\text { Treatment Plant }\end{array}$ \\
\hline $\begin{array}{l}\text { Glaze and Engobe } \\
\text { preparation } \\
\text { section }\end{array}$ & Glaze & Glaze application & Waste Glaze & $\begin{array}{l}\text { Effluent } \\
\text { Treatment Plant }\end{array}$ \\
\hline $\begin{array}{l}\text { Engineering } \\
\text { Department }\end{array}$ & Water & $\begin{array}{l}\text { Tile edge } \\
\text { cleaning } \\
\text { Printing } \\
\text { application }\end{array}$ & & \\
\hline $\begin{array}{l}\text { Ink Preparation } \\
\text { Section }\end{array}$ & Printing ink, & & & \\
\hline $\begin{array}{l}\text { M/s. Colorobbia } \\
\text { - Spain }\end{array}$ & Ready-made ink & & & \\
\hline $\begin{array}{l}\text { M/s. ZGC - } \\
\text { China }\end{array}$ & & $\begin{array}{l}\text { Glazed and } \\
\text { printed tiles } \\
\text { loading to the } \\
\text { trolleys }\end{array}$ & $\begin{array}{l}\text { Trolley with } \\
\text { glazed and } \\
\text { printed tiles }\end{array}$ & $\begin{array}{l}\text { Glost Kiln (2nd } \\
\text { Firing) }\end{array}$ \\
\hline
\end{tabular}


NSBM Journal of Management

Vol. 1, No. 2, July-December, 2015

Table 4: Critical Paths of the Glazing and Printing Process

\begin{tabular}{|c|c|c|c|c|}
\hline \multicolumn{2}{|c|}{$\begin{array}{c}\text { Supplier Process (Internal/ } \\
\text { External) }\end{array}$} & \multicolumn{2}{|c|}{ Business Process } & \multirow{2}{*}{$\begin{array}{c}\text { Customer } \\
\text { Process } \\
\text { (Internal) } \\
\text { VOC }\end{array}$} \\
\hline CTS & CTI & CTP & CTQ & \\
\hline \multirow[t]{2}{*}{$\begin{array}{l}\text { Glaze } \\
\text { Preparation } \\
\text { Section }\end{array}$} & $\begin{array}{l}\text { Engobe, } \\
\text { glazes }\end{array}$ & $\begin{array}{l}\text { Engobe and Glaze } \\
\text { application }\end{array}$ & $\begin{array}{l}\text { Correct amount of } \\
\text { engobe and glaze on } \\
\text { the tiles }\end{array}$ & $\begin{array}{l}\text { Tiles with right } \\
\text { glaze and Engobe } \\
\text { weights }\end{array}$ \\
\hline & Glazed title & Edge cleaning & $\begin{array}{l}\text { Setting the Edge } \\
\text { cleaning as required. }\end{array}$ & $\begin{array}{l}\text { Tiles with clean } \\
\text { edges }\end{array}$ \\
\hline $\begin{array}{l}\text { Glaze } \\
\text { Preparation } \\
\text { Section }\end{array}$ & $\begin{array}{l}\text { Prepared ink } \\
\text { /Digital ink }\end{array}$ & Printing & & \\
\hline $\begin{array}{l}\text { M/s. Colorobbia } \\
\text { - Spain }\end{array}$ & & $\begin{array}{l}\text { Loading the glazed } \\
\text { tiles to the cars. }\end{array}$ & $\begin{array}{l}\text { Registers the print } \\
\text { without any print } \\
\text { defect. }\end{array}$ & \\
\hline $\begin{array}{l}\mathrm{M} / \mathrm{s} . \mathrm{ZGC}- \\
\text { China }\end{array}$ & & & $\begin{array}{l}\text { No damage to the } \\
\text { glazed tiles at the time } \\
\text { of loading }\end{array}$ & $\begin{array}{l}\text { Properly loaded } \\
\text { glazed cars } \\
\text { (trolley) }\end{array}$ \\
\hline
\end{tabular}

Note: All critical areas were highlighted where action was required to improve the process and all measurements were carried out to gauge the size of the problem and to identify the sources of variations. Once the critical path is identified, the Define stage of DMAIC ends and the Measurement stage begins. 
Application of Six Sigma Methodology in Glazing and Printing Processes: The Case of Lanka Wall Tiles PLC

\begin{tabular}{|c|c|c|c|c|c|c|c|c|c|c|c|c|c|c|c|c|c|c|}
\hline \multicolumn{6}{|c|}{ 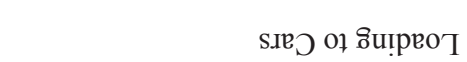 } & & & ' & & & & $\approx$ & $\bullet$ & ' & & 1 & & $\because$ \\
\hline \multicolumn{6}{|c|}{ 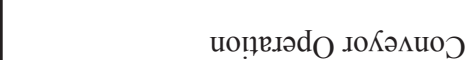 } & & & 1 & & $\cong$ & 0 & $\approx$ & $\bullet$ & , & & 1 & & \& \\
\hline \multicolumn{6}{|c|}{ 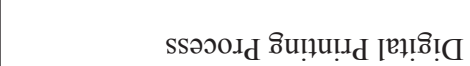 } & & & $\cong$ & $\bullet$ & ' & & $\because$ & 0 & ' & & ' & & ले \\
\hline \multicolumn{6}{|c|}{ ssəoo.. } & $a$ & 0 & 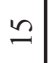 & • & ' & & $\because$ & 0 & ' & & ' & & ले \\
\hline \multicolumn{6}{|c|}{ ssəəo.ı } & & & $\simeq$ & $\bullet$ & & & $\approx$ & $\bullet$ & & & $\approx$ & $\bullet$ & 6 \\
\hline \multicolumn{6}{|c|}{ ภิน!ฺยวว วઠิрә ә!ు } & 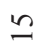 & $\bullet$ & 1 & & ' & & $\approx$ & $\bullet$ & ' & & 1 & & F \\
\hline \multicolumn{6}{|c|}{ uо!̣вอ! [dd } & 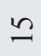 & $\bullet$ & & & & & $\because$ & 0 & in & - & $\cong$ & 0 & in \\
\hline \multicolumn{6}{|c|}{ 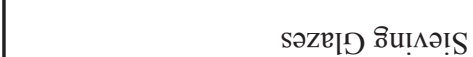 } & $\because$ & $\bullet$ & 1 & & ' & & . & & in & - & $\because$ & 0 & $\ddot{m}$ \\
\hline \multicolumn{6}{|c|}{ 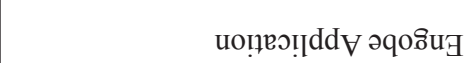 } & $\because$ & $\bullet$ & & & & & $\because$ & 0 & $n$ & - & $\because$ & 0 & in \\
\hline \multicolumn{6}{|c|}{ วqоภินี ภืน!ฺว!S } & $\cong$ & $\bullet$ & 1 & & ' & & 1 & & in & $\bullet$ & $\because$ & 0 & m \\
\hline \multicolumn{6}{|c|}{ 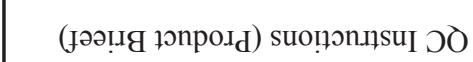 } & 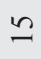 & $\bullet$ & & & & & $\approx$ & $\bullet$ & n & $\bullet$ & $\approx$ & $\bullet$ & 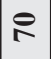 \\
\hline \multicolumn{6}{|c|}{ ภิu!̣ుsn.tg } & $a$ & 0 & 1 & & ' & & 1 & & $\sim$ & & $\approx$ & $\bullet$ & ले \\
\hline \multicolumn{6}{|c|}{ 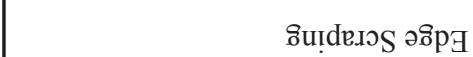 } & $m$ & 7 & , & & $\cong$ & 0 & 1 & & - & & $\operatorname{nn}$ & 口 & $\ddot{\sim}$ \\
\hline \multicolumn{6}{|c|}{ 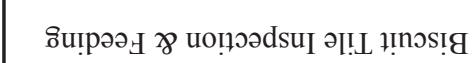 } & $m$ & 工 & & & $\approx$ & $\bullet$ & 1 & & ' & & $\because$ & 0 & $\dddot{F}$ \\
\hline \multicolumn{6}{|c|}{ (Küduos) sిu!̣ా } & $m$ & & $m$ & & $n$ & & $n$ & & - & & in & & \\
\hline \multirow[t]{2}{*}{ 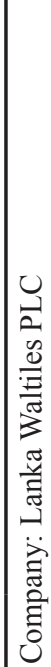 } & \multirow[t]{2}{*}{ 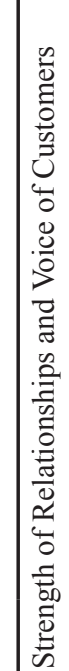 } & 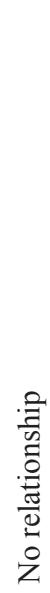 & 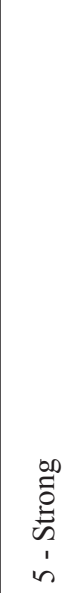 & 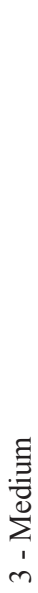 & $\begin{array}{l}\frac{y}{\tilde{J}} \\
\frac{D}{3} \\
1\end{array}$ & & 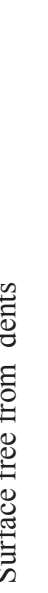 & 年 & 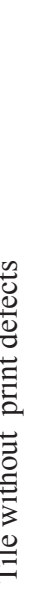 & & 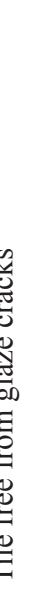 & $\begin{array}{l}0 \\
0 \\
0 \\
0\end{array}$ & 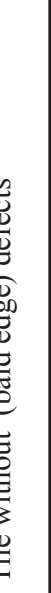 & 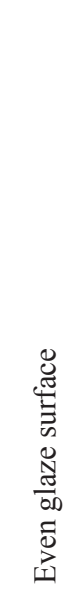 & & 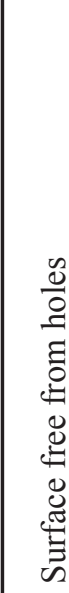 & 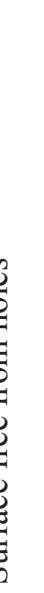 & $\begin{array}{l}\overline{\tilde{\pi}} \\
\text { อे }\end{array}$ \\
\hline & & । & • & 0 & ロ & & - & & i & & $\dot{r}$ & 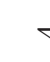 & j & $\dot{r}$ & & $0^{\circ}$ & & \\
\hline
\end{tabular}




\section{NSBM Journal of Management}

Vol. 1, No. 2, July-December, 2015

Basic level QFD highlights the operations, viz. quality control, engobe, glaze and printing operations, as the most important ones (CTP) where opportunities exist for improvement. The outcomes of QFD are depicted in Chart 2. QFD helped project to identify critical to qualities (CTQ) and critical processes. (CTP). However, the above QFD has not analyzed the competitor's capability as against the company performance since the data is not available.

Once the process was established, the next step was to appoint a team from among the process owners and assign them with tasks based on their capabilities for conducting the project. Team members and their roles are identified prior to the formal study. Table 8 indicates the members of the team that was appointed and their roles.

\section{Table 5: Team Role Matrix}

\begin{tabular}{|c|c|c|c|c|}
\hline Position & Category & $\begin{array}{c}\text { Project } \\
\text { Management Role }\end{array}$ & Technical Role & $\begin{array}{c}\text { Technical Working } \\
\text { Role }\end{array}$ \\
\hline Head of Finance (HOF) & Champion & $\begin{array}{l}\text { Approval, Review } \\
\text { provide resources }\end{array}$ & & \\
\hline Factory Manager (FM) & Team Leader & $\begin{array}{l}\text { Execution of the } \\
\text { project plan. }\end{array}$ & $\begin{array}{l}\text { Support the team to } \\
\text { analyze data }\end{array}$ & Motivate the team \\
\hline $\begin{array}{l}\text { Assist. Factory Manager } \\
\text { (Production) }(\mathrm{AFM}-\mathrm{P})\end{array}$ & Team Members & Documentation & $\begin{array}{l}\text { Support to analyze } \\
\text { data }\end{array}$ & \\
\hline $\begin{array}{l}\text { Assist. Production } \\
\text { Manager I (APM - I) }\end{array}$ & & Proposing controls & Technical ideas & \\
\hline $\begin{array}{l}\text { Production Executive } \\
\text { (Glaze Preparation) (PE } \\
-\mathrm{G} / \mathrm{P})\end{array}$ & & Proposing controls & Technical ideas & \\
\hline $\begin{array}{l}\text { Production Executive } \\
\text { (Glazing) }(\mathrm{PE}-\mathrm{G})\end{array}$ & & Data Analysis & & \\
\hline $\begin{array}{l}\text { Assist. Quality } \\
\text { Assurance Executive } \\
\text { (AQAE) }\end{array}$ & & Data collection & & \\
\hline $\begin{array}{l}\text { National Institute of } \\
\text { Business Management } \\
\text { (NIBM) }\end{array}$ & Mentor & Monitoring & Technical ideas & Facilitation \\
\hline
\end{tabular}

\section{Standardization of the Current Process}

At the beginning of the study, it was decided to standardize the process in order to easily identify the variations in the process. Table 6 presents the current operations and proposed operations after standardization to improve the quality of the process at the Define stage. 
Application of Six Sigma Methodology in Glazing and Printing Processes:

The Case of Lanka Wall Tiles PLC

Table 6: Action Plan for Standardization of the Process

\begin{tabular}{|c|c|c|c|c|}
\hline & Operation & Current Operation & Proposed Operation & Responsibility \\
\hline 1. & Receipt of biscuit tiles & Unskilled operator & Deploy skilled operator & Production Executive \\
\hline 2. & Receipt of glaze/engobe & $\begin{array}{l}\text { Use glazes as and when } \\
\text { received. }\end{array}$ & $\begin{array}{l}\text { Keep } 15 \text { minutes under } \\
\text { agitation }\end{array}$ & Production Executive \\
\hline 3 & $\begin{array}{l}\text { Glaze \&engobe } \\
\text { application }\end{array}$ & $\begin{array}{l}\text { Check viscosity and } \\
\text { density every } 30 \mathrm{~min}\end{array}$ & $\begin{array}{l}\text { Check viscosity and } \\
\text { density every } 30 \mathrm{~min}\end{array}$ & Production Executive \\
\hline 4. & Scraping method & Check every 4 hrs. & Check every 2 hours & Production Executive \\
\hline 5. & Loading method & $\begin{array}{l}\text { Inform when there is a } \\
\text { problem only }\end{array}$ & $\begin{array}{l}\text { Check and regulate } \\
\text { trolley irregularities } \\
\text { monthly }\end{array}$ & Production Executive \\
\hline 6. & Conveyor maintenance & $\begin{array}{l}\text { Condition report sent } \\
\text { to Engineering Dept. } \\
\text { before maintenance day. }\end{array}$ & $\begin{array}{l}\text { Condition report sent to } \\
\text { Engineering Dept. daily. }\end{array}$ & Production Executive \\
\hline
\end{tabular}

\section{Measurement Stage}

This consisted of two activities: data collection using the Planning Sheet and conceptualization of the independent variables which impact on the yield of glazing and printing processes. Figure 3 depicts the variables (Xs), which need to be improved and controlled for a better yield.

Figure 3: Conceptual Model for Process Improvement

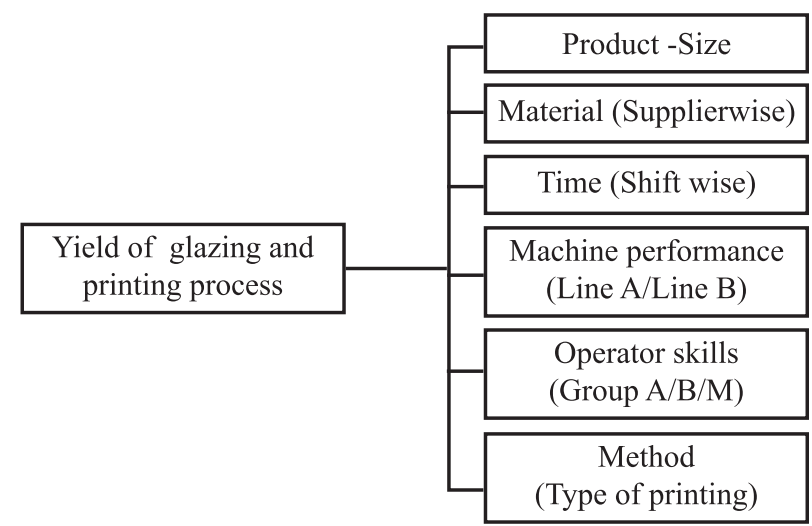

The variables (Xs) were identified by the team based on the product knowledge and the literature. 
NSBM Journal of Management

Vol. 1, No. 2, July-December, 2015

Table 7: Planning Sheet - Measurement Stage

\begin{tabular}{|c|c|c|c|c|c|c|}
\hline & Process Step & CTQ & $\begin{array}{l}\text { Operational } \\
\text { Definition }\end{array}$ & Data Type & Stratification & Sample Size \\
\hline 1 & Biscuit Feeding & $\begin{array}{l}\text { Tiles with } \\
\text { glaze/crack }\end{array}$ & $\begin{array}{l}\text { As per } \\
\text { specification } \\
\text { of biscuit tile } \\
\text { inspection }\end{array}$ & Count data & $\begin{array}{l}\text { Biscuit tile } \\
\text { inspectors }\end{array}$ & $\begin{array}{l}20 \text { pcs per hour } \\
(320 \text { per/day) }\end{array}$ \\
\hline 2 & $\begin{array}{l}\text { Biscuit tile } \\
\text { surface } \\
\text { cleaning } \\
\text { (Brushing) }\end{array}$ & Tiles with holes & $\begin{array}{l}\text { Tiles with organic } \\
\text { material and durst } \\
\text { on the surface as } \\
\text { per the sample }\end{array}$ & Count data & $\begin{array}{l}\text { Conveyor } \\
\text { operator-wise }\end{array}$ & $\begin{array}{l}20 \text { pcs per hour } \\
(320 \mathrm{per} / \text { day })\end{array}$ \\
\hline 3 & $\begin{array}{l}\text { Glaze edge } \\
\text { Scraping }\end{array}$ & $\begin{array}{l}\text { Tiles with bald } \\
\text { edge defects }\end{array}$ & $\begin{array}{l}\text { (a) Poor bonding } \\
\text { properly of glazes. } \\
\text { (b) Improper } \\
\text { settings of edge } \\
\text { scraping unit. }\end{array}$ & Count data & $\begin{array}{l}\text { Type of tiles } \\
\text { Conveyor } \\
\text { operator-wise }\end{array}$ & $\begin{array}{l}20 \mathrm{pcs} \text { per hour } \\
(320 \mathrm{per} / \text { day })\end{array}$ \\
\hline 4 & $\begin{array}{l}\text { Engobe } \\
\text { Application }\end{array}$ & $\begin{array}{l}\text { Tiles with } \\
\text { engobe hump }\end{array}$ & $\begin{array}{l}\text { Settling solid } \\
\text { particles on glazed } \\
\text { application unit }\end{array}$ & Count data & $\begin{array}{l}\text { Glaze } \\
\text { application unit } \\
\text { (Bell)-wise }\end{array}$ & $\begin{array}{l}20 \mathrm{pcs} \text { per hour } \\
(320 \mathrm{per} / \text { day })\end{array}$ \\
\hline 5 & $\begin{array}{l}\text { Glaze } \\
\text { Application }\end{array}$ & Tiles with dents & $\begin{array}{l}\text { Bubble forming in } \\
\text { the glaze }\end{array}$ & Count data & Glaze tub-wise & $\begin{array}{l}20 \mathrm{pcs} \text { per hour } \\
(320 \mathrm{per} / \text { day })\end{array}$ \\
\hline
\end{tabular}

Based on the Critical to Quality (CTQ) factors and their measurements, a further analysis of the data was carried out to identify sources of variation using appropriate statistical tools.

\section{Analysis Stage}

With the data in the measurement stage, a Pareto analysis (Chart 3), Control Chart analysis (Chart 4), visual observation to identify sources of variation (Figure 4), and cross tabulations of probabilities of different defects by different sources of variation (Table 11-16) were carried out. The sources of variation taken were glaze type (Table 11), different combinations (Table 12), shift (Table 13), operator group (Table 14), print type (Table 15) and glazing line type (Table 16). 
Application of Pareto Analysis

The results of the Pareto analysis appear in Chart 3.

\section{Chart 3: Pareto Analysis for Defects}

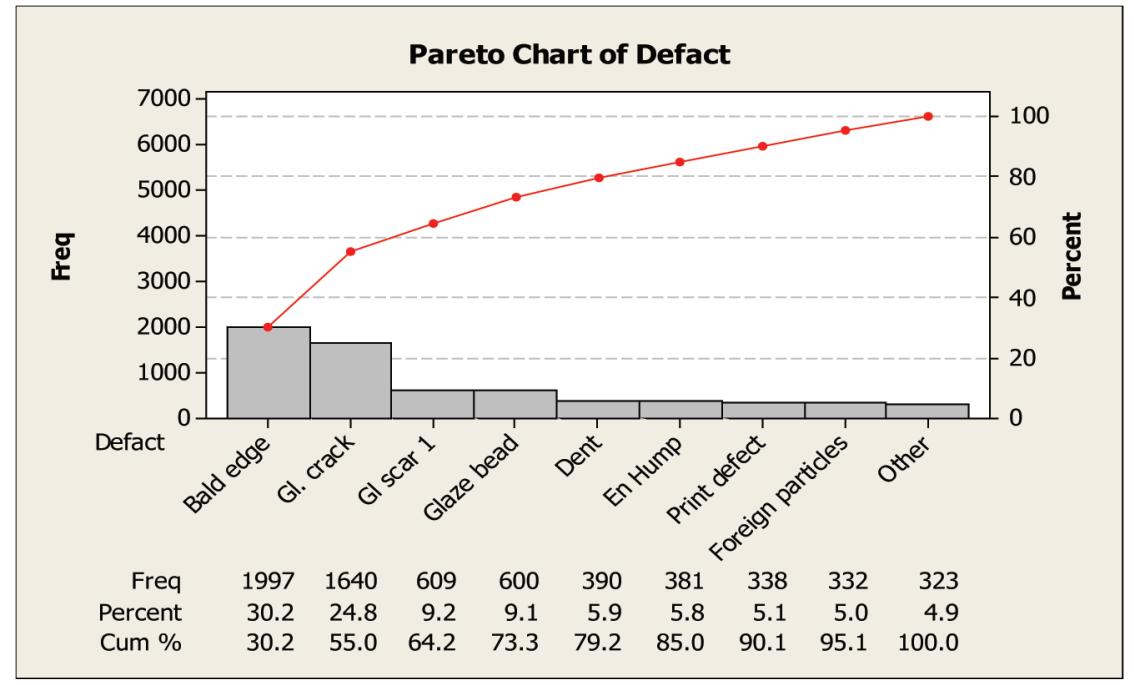

The analysis shows that bald edges, glaze cracks, glaze scars 1, glaze beads and dents accounted for 79.2 percent of the defects, the rest of the contributory factors were of less significance which accounted for the balance 19.8 percent of the defects. Hence, the focus of the study hereafter was on the first five types of defects and causes for which were identified through control charts and other statistical tools.

\section{Application of Control Charts}

Control charts measure the stability of a process and help to separate special causes from natural causes. Natural causes are made up of a large numbers of micro variations which demand a huge investment to control but the results are negligible. Hence control charts were used to identify the special variations. P-charts which are meant to attribute data help to identify special causes, which affect process stability. Chart 4 shows that there is no stability at all in daily outputs of Plant A and variations are considered to be very high with a mean rejection rate of 32 percent of the total outputs for the day. 
NSBM Journal of Management

Vol. 1, No. 2, July-December, 2015

Chart 4: P-Chart Analysis of Daily Rejects

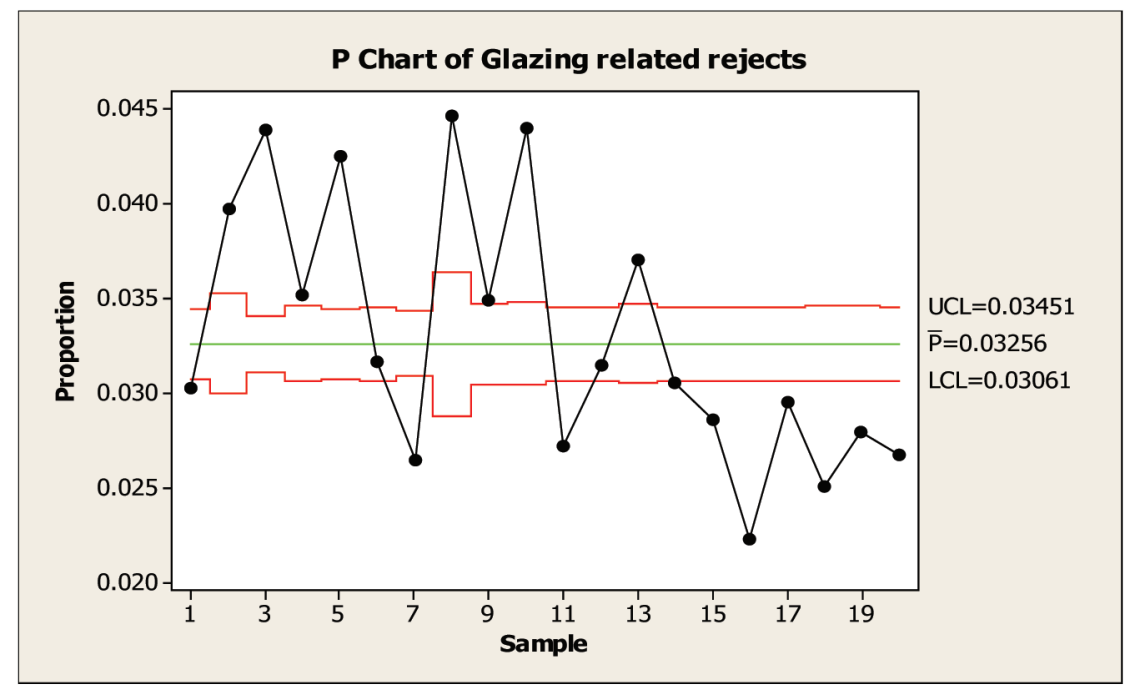

The same analysis was done for different types of defects and the results are depicted in Chart 5. It shows that all of them are not stable and statistically not in control. Hence it is necessary to identify the special causes and their variations. The analysis identified a few critical opportunities. All major defects were identified and are shown in Figure 4. The first stage of improvement is process standardization and the second stage is making the process stable by removing the sources of major variations. At a glance. it is obvious that all operations are not stable and it is evident that there is a huge variation in production.

Though there are no specific patterns or trends in the charts, they indicate that all of them are not in control and there is a need to identify the major causes of the process deviation. A study was conducted to locate all out-of-control points and find out the specific reasons as to why the deviations were evident. All these causes were displayed in the cause and effect diagram as shown in Figure 5. 


\section{Chart 5: Analysis of Different Types of Defects}
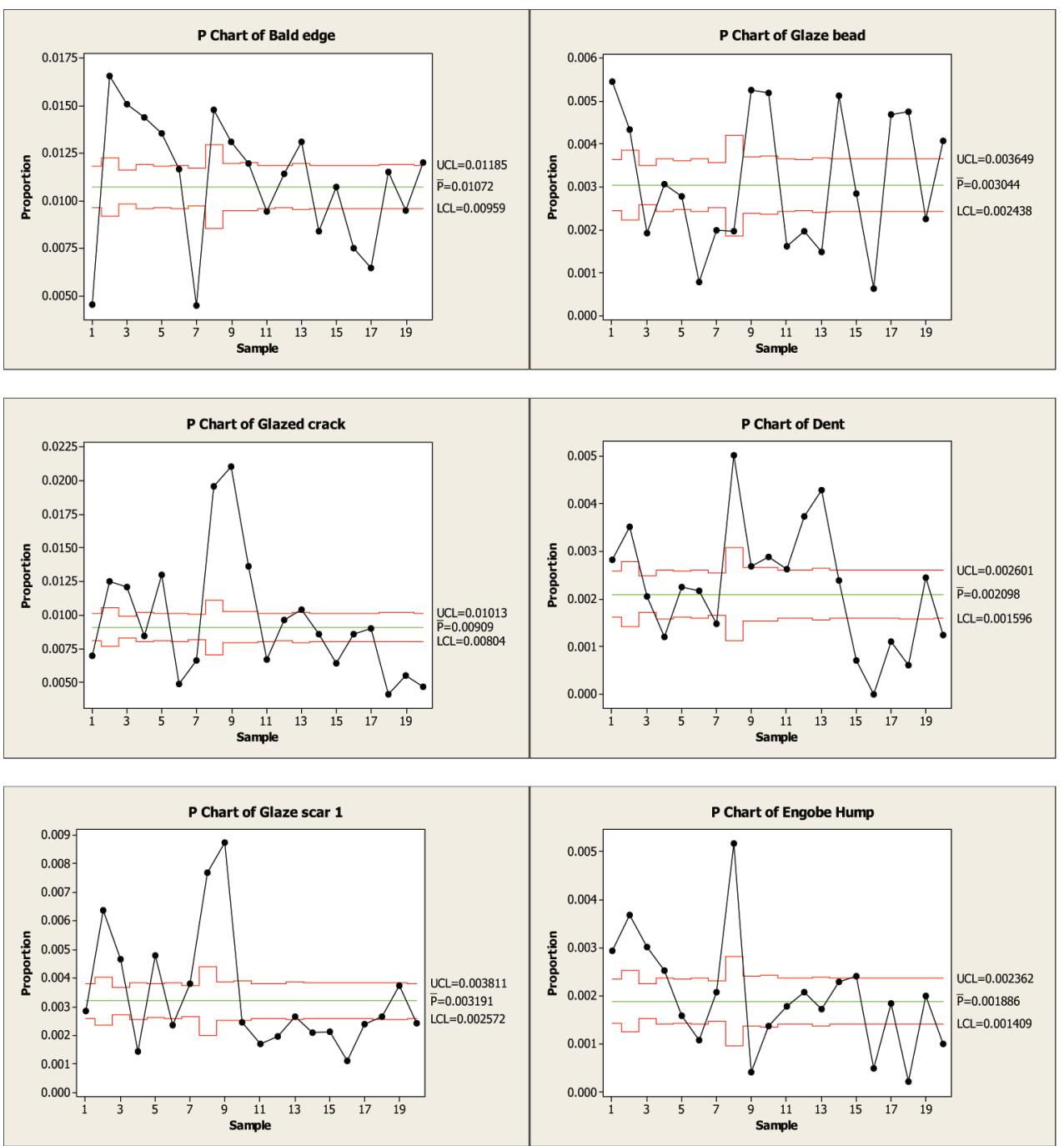

Visual observation helps to identify the sources of variation and actually what occurs at the time production (see Figure 4). 
NSBM Journal of Management

Vol. 1, No. 2, July-December, 2015

Figure 4: Visualization of Critical Defects
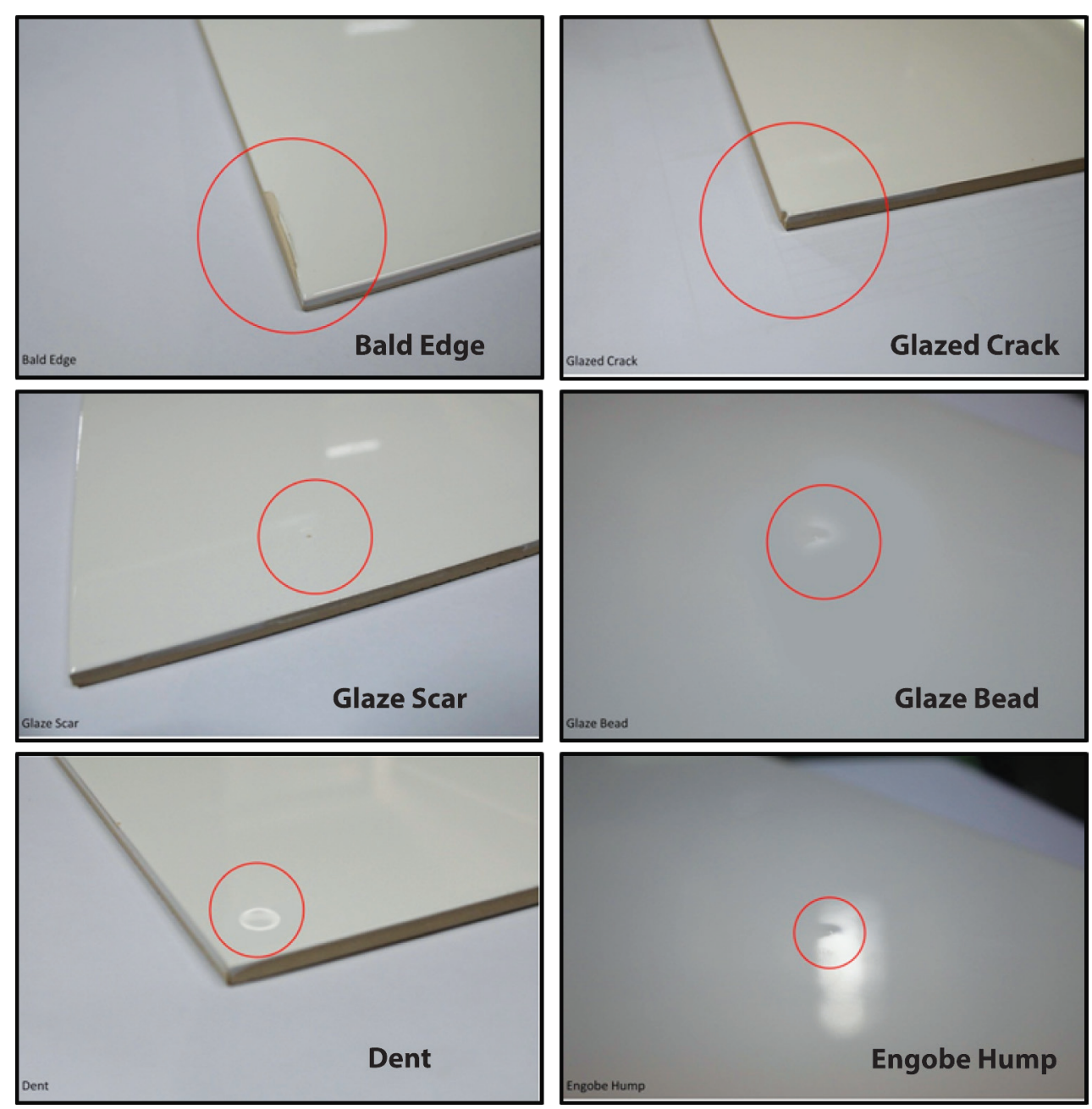

In order to analyze further, a cross tabulation was conducted for types of defects versus glaze type as shown in Table 8. 
Application of Six Sigma Methodology in Glazing and Printing Processes: The Case of Lanka Wall Tiles PLC

Table 8: Cross Tabulation of Probability of Defect Type vs. Glaze Type

\begin{tabular}{llll}
\hline & Opaque & Colorobbia- Spain & OP \\
\cline { 2 - 4 } & & ZGC - China & OC \\
\cline { 2 - 4 } Glaze Type & Semi Opaque & Colorobbia & SO \\
\cline { 2 - 4 } & & Colorobbia/ZGC(1:1) & SC \\
\cline { 2 - 4 } & Transparent & Full (T03) & FT \\
\cline { 2 - 4 } & & Normal (T01) & NT \\
\cline { 2 - 4 } & Normal Matt & & NM \\
\cline { 2 - 4 } & Digital Matt & & DM \\
\hline
\end{tabular}

Table 9: Probability of Different Combinations of Defects

\begin{tabular}{crrrrrr}
\hline Row Labels & $\begin{array}{c}\text { Sum of Bald } \\
\text { edge }\end{array}$ & $\begin{array}{c}\text { Sum of Gl. } \\
\text { crack }\end{array}$ & $\begin{array}{c}\text { Sum of GI } \\
\text { scar 1 }\end{array}$ & $\begin{array}{c}\text { Sum of } \\
\text { Glaze bead }\end{array}$ & Sum of Dent & $\begin{array}{c}\text { Sum of En } \\
\text { Hump }\end{array}$ \\
\hline CT & $0.60 \%$ & $0.00 \%$ & $0.00 \%$ & $0.33 \%$ & $0.00 \%$ & $0.00 \%$ \\
DM & $1.70 \%$ & $2.68 \%$ & $3.12 \%$ & $6.00 \%$ & $0.00 \%$ & $0.52 \%$ \\
FT & $10.22 \%$ & $5.43 \%$ & $5.58 \%$ & $2.67 \%$ & $10.77 \%$ & $13.12 \%$ \\
NM & $27.09 \%$ & $25.06 \%$ & $16.09 \%$ & $35.17 \%$ & $0.77 \%$ & $0.26 \%$ \\
NT & $16.17 \%$ & $17.44 \%$ & $14.61 \%$ & $7.67 \%$ & $16.15 \%$ & $12.86 \%$ \\
OC & $13.97 \%$ & $15.91 \%$ & $16.09 \%$ & $19.83 \%$ & $19.49 \%$ & $30.45 \%$ \\
OP & $16.47 \%$ & $16.65 \%$ & $14.45 \%$ & $15.17 \%$ & $26.92 \%$ & $14.44 \%$ \\
SC & $7.41 \%$ & $13.05 \%$ & $23.48 \%$ & $10.17 \%$ & $19.74 \%$ & $22.05 \%$ \\
SO & $6.36 \%$ & $3.78 \%$ & $6.57 \%$ & $3.00 \%$ & $6.15 \%$ & $6.30 \%$ \\
Total & $100.00 \%$ & $100.00 \%$ & $100.00 \%$ & $100.00 \%$ & $100.00 \%$ & $100.00 \%$ \\
\hline
\end{tabular}

Table 9 shows that the glaze type had different levels and percentages of defects in the production process. 
NSBM Journal of Management

Vol. 1, No. 2, July-December, 2015

Table 10: Cross Tabulation of Probability of Defect Type vs. Shift

\begin{tabular}{|c|c|c|c|c|c|c|}
\hline & & \multicolumn{4}{|l|}{ Morning } & M \\
\hline \multicolumn{2}{|c|}{ Shift } & \multicolumn{4}{|l|}{ Evening } & $\mathrm{E}$ \\
\hline & & \multicolumn{4}{|l|}{ Night } & $\mathrm{N}$ \\
\hline Row Labels & $\begin{array}{c}\text { Sum of Bald } \\
\text { edge }\end{array}$ & $\begin{array}{l}\text { Sum of Gl. } \\
\text { crack }\end{array}$ & $\begin{array}{l}\text { Sum of Gl } \\
\text { scar } 1\end{array}$ & $\begin{array}{c}\text { Sum of } \\
\text { Glaze bead }\end{array}$ & Sum of Dent & $\begin{array}{c}\text { Sum of En } \\
\text { Hump }\end{array}$ \\
\hline M & $41.41 \%$ & $36.59 \%$ & $28.08 \%$ & $42.83 \%$ & $35.38 \%$ & $33.33 \%$ \\
\hline $\mathbf{E}$ & $34.35 \%$ & $32.74 \%$ & $42.36 \%$ & $37.67 \%$ & $35.13 \%$ & $37.27 \%$ \\
\hline $\mathbf{N}$ & $24.24 \%$ & $30.67 \%$ & $29.56 \%$ & $19.50 \%$ & $29.49 \%$ & $29.40 \%$ \\
\hline Total & $100.00 \%$ & $100.00 \%$ & $100.00 \%$ & $100.00 \%$ & $100.00 \%$ & $100.00 \%$ \\
\hline
\end{tabular}

Table10 indicates that shifts make a difference in the production of defects and their impact is not significant as there is no significant variation in the rates of the defects identified, from the type of shift.

Table11: Cross Tabulation of Probability of Defect Type vs. Operator Group

\begin{tabular}{|c|c|c|c|c|c|c|}
\hline \multirow{2}{*}{\multicolumn{2}{|c|}{ Operator Group }} & \multirow{2}{*}{\multicolumn{4}{|c|}{ Plant A glazing line operator group }} & \multirow{2}{*}{$\begin{array}{l}\mathrm{A} \\
\mathrm{B} \\
\mathrm{M}\end{array}$} \\
\hline & & & & & & \\
\hline Row Labels & $\begin{array}{c}\text { Sum of Bald } \\
\text { edge }\end{array}$ & $\begin{array}{l}\text { Sum of Gl. } \\
\text { crack }\end{array}$ & $\begin{array}{l}\text { Sum of Gl } \\
\text { scar } 1\end{array}$ & $\begin{array}{c}\text { Sum of } \\
\text { Glaze bead }\end{array}$ & Sum of Dent & $\begin{array}{c}\text { Sum of En } \\
\text { Hump }\end{array}$ \\
\hline $\mathbf{A}$ & $40.11 \%$ & $38.48 \%$ & $36.45 \%$ & $39.00 \%$ & $35.13 \%$ & $27.30 \%$ \\
\hline B & $34.10 \%$ & $28.84 \%$ & $30.21 \%$ & $40.00 \%$ & $32.05 \%$ & $41.21 \%$ \\
\hline $\mathbf{M}$ & $25.79 \%$ & $32.68 \%$ & $33.33 \%$ & $21.00 \%$ & $32.82 \%$ & $31.50 \%$ \\
\hline Total & $100.00 \%$ & $100.00 \%$ & $100.00 \%$ & $100.00 \%$ & $100.00 \%$ & $100.00 \%$ \\
\hline
\end{tabular}

Three different operatives' groups were defined as per the shifts attended.

Table 11 indicates that the operator group influences the production of defective items and that the impact is significant. The bald edge defect and glaze bead defect are directly associated with the employees' skill and it can be seen that Group M's skills are better than those of the others. The other defects are not associated with the skills and also there is no significant difference of defects percentages Vis a Vis the employee groups. 
Table 12: Cross Tabulation of Probability of Defect Type vs. Print Type

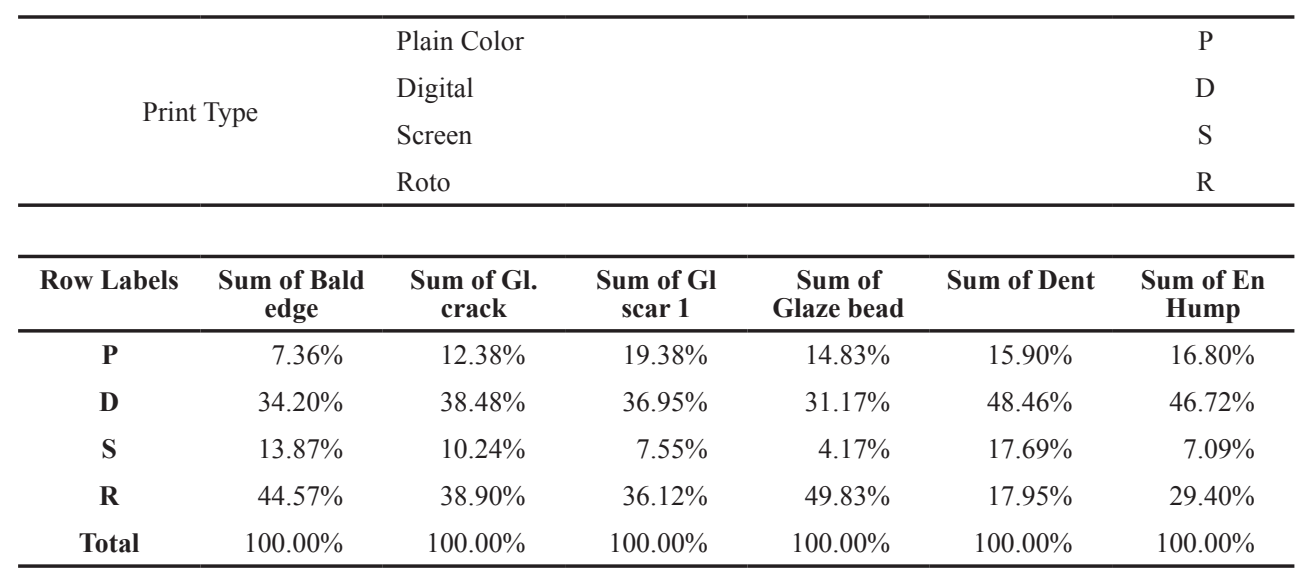

Table12 indicates that there is a variation of defects based on the type of prints, which is a significant reason for defective items.

Table13: Cross Tabulation of Probability of Defect Type vs. Glazing Line

\begin{tabular}{|c|c|c|c|c|c|c|}
\hline \multirow{2}{*}{\multicolumn{2}{|c|}{ Glazing Line }} & \multirow{2}{*}{\multicolumn{4}{|c|}{$\begin{array}{l}\text { Glazing Line A } \\
\text { Glazing Line B }\end{array}$}} & \multirow{2}{*}{$\begin{array}{l}\text { A } \\
\text { B }\end{array}$} \\
\hline & & & & & & \\
\hline Row Labels & $\begin{array}{c}\text { Sum of Bald } \\
\text { edge }\end{array}$ & $\begin{array}{l}\text { Sum of Gl. } \\
\text { crack }\end{array}$ & $\begin{array}{l}\text { Sum of Gl } \\
\text { scar } 1\end{array}$ & $\begin{array}{c}\text { Sum of } \\
\text { Glaze bead }\end{array}$ & Sum of Dent & $\begin{array}{c}\text { Sum of En } \\
\text { Hump }\end{array}$ \\
\hline $\mathbf{A}$ & $57.94 \%$ & $55.24 \%$ & $58.29 \%$ & $47.00 \%$ & $60.00 \%$ & $44.09 \%$ \\
\hline B & $42.06 \%$ & $44.76 \%$ & $41.71 \%$ & $53.00 \%$ & $40.00 \%$ & $55.91 \%$ \\
\hline Total & $100.00 \%$ & $100.00 \%$ & $100.00 \%$ & $100.00 \%$ & $100.00 \%$ & $100.00 \%$ \\
\hline
\end{tabular}

Table13 indicates that there is a significant variation arising between the two different glazing production lines, which needs due attention. (Better to say Lines I and II because we talk about Plant B in the paper early on).

The final activity of the Analysis stage constituted identifying the causes of defects in the production process. This was carried out using the Ishikawa diagram through a few rounds of brainstorming sessions involving both workers and supervisory staff (refer Figure 5). The results were tabulated as depicted in Table 14. 
NSBM Journal of Management

Vol. 1, No. 2, July-December, 2015

Figure 5: Cause and Effect Diagram for Generating Defects

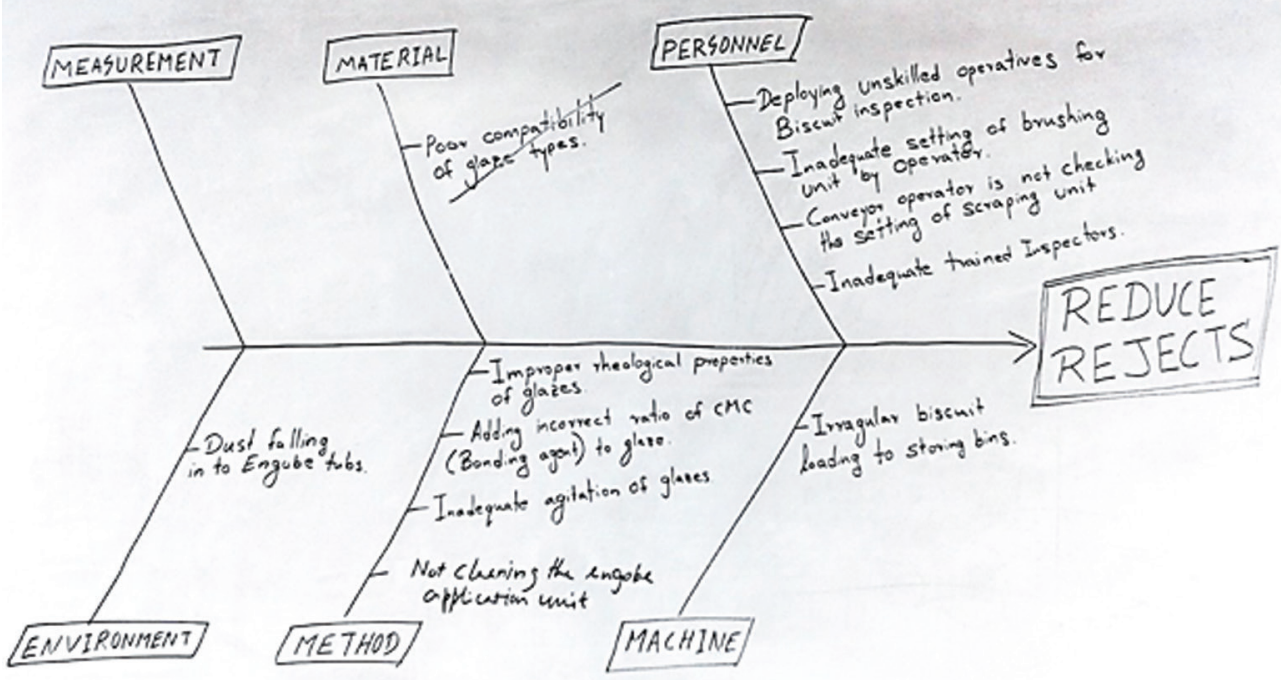

Table 14: Identification of Causes

\begin{tabular}{|c|c|c|c|}
\hline Defect & Error in the Process & Location & Cause \\
\hline \multirow[t]{2}{*}{ Bald edge } & $\begin{array}{l}\text { a. Poor bonding } \\
\text { property in glaze }\end{array}$ & Glaze preparation section & $\begin{array}{l}\text { Adding the incorrect ratio } \\
\text { of CMC (bonding agent) } \\
\text { to the glaze. }\end{array}$ \\
\hline & $\begin{array}{l}\text { b. Improper } \\
\text { settings of edge scraping } \\
\text { unit }\end{array}$ & Scraping unit & $\begin{array}{l}\text { Operator is not checking } \\
\text { proper setting of scraping } \\
\text { unit. }\end{array}$ \\
\hline \multirow[t]{2}{*}{ Glazed crack } & $\begin{array}{l}\text { Passing defective biscuit } \\
\text { tiles to the glazing } \\
\text { process }\end{array}$ & Biscuit feeding location & $\begin{array}{l}\text { Deploying un-skilled } \\
\text { operatives for biscuit } \\
\text { inspection. }\end{array}$ \\
\hline & & & $\begin{array}{l}\text { Irregular biscuit loading } \\
\text { to storage bins }\end{array}$ \\
\hline Glaze scar1 & $\begin{array}{l}\text { Organic material and dust } \\
\text { on the tiles. }\end{array}$ & $\begin{array}{l}\text { Brushing unit fixed to } \\
\text { clean biscuit tiles. }\end{array}$ & $\begin{array}{l}\text { Inadequate setting of } \\
\text { brushing unit by the } \\
\text { operator. }\end{array}$ \\
\hline Glaze bead & Clogging the glaze & Glaze application unit & $\begin{array}{l}\text { Improper setting of } \\
\text { rheological properties of } \\
\text { the glaze by QAD. }\end{array}$ \\
\hline Dent & $\begin{array}{l}\text { Bubble formation in the } \\
\text { glaze. }\end{array}$ & Glaze tub & $\begin{array}{l}\text { In advocate agitation of } \\
\text { the glaze. }\end{array}$ \\
\hline \multirow[t]{2}{*}{ Engobe hump } & $\begin{array}{l}\text { Clogging of engobe Dust } \\
\text { falling into the engobe } \\
\text { tub }\end{array}$ & Engobe application unit & $\begin{array}{l}\text { Not cleaning the engobe } \\
\text { application unit every } \\
\text { shift }\end{array}$ \\
\hline & & & $\begin{array}{l}\text { Not having a lid for the } \\
\text { engobe tubs }\end{array}$ \\
\hline
\end{tabular}




\section{Improvement Stage}

The following recommendations were implemented to mitigate the sources of variation. Action was taken to increase the amount of CMC (Bonding agent) added to glaze from $0.05 \%$ to $0.1 \%$ in order to reduce the bold edge defect as suggested by the Factory Manager (Team Leader). A trial conducted by the Quality Assurance Department found a 58\% reduction in bald-edge defects after increasing $\mathrm{CMC}$.

i. Steps were taken to train all the unskilled biscuit inspectors as suggested by the Assistant Factory Manager (Production) (Team Member) and deploy only the skilled inspectors for biscuit tile inspection to reduce the glazed crack defects. SOP was introduced for eligibility to become a Biscuit Tile Inspector by the Production Executive (Glazing) (Team Member).

ii. Steps were taken to monitor the brushing unit operation by Supervisory Assistants every four hours and to cover the glaze and engobe tub to protect falling dust into the glaze tanks.

iii. Action was taken by the Production Executive (Glazing) to clean the engobe application unit every eight hours in order to avoid particles settling on the engobe application unit (Bell) which created engobe hump defects.

iv. The process was standardized in order to ensure sustainable results as suggested by the Assistant Production Manager I.

\section{Control Stage}

The following steps were taken as measures for controlling the improved process. These were effected in full from January 2015.

i. A checklist was prepared for checking biscuit tile inspection operations.

ii. The six types of defect that were identified were displayed in a control chart in the glazing and printing section by the line management as a constant reminder for workers and supervisory staff.

iii. All the Quality Control instruction sheets (product brief) are reviewed daily by the Supervisory Assistants to ensure the reliability of the process.

iv. The quality of the glazed tiles loaded to the trolleys is monitored by the Supervisory Assistant in the glazing section in four hourly intervals. 
NSBM Journal of Management

Vol. 1, No. 2, July-December, 2015

v. All the check lists/ control charts are reviewed weekly by the supervisors and monthly by the sectional head.

vi. Carry out audits for routine operations and setting activities (change over time and shut down time) are conducted by the Sectional Head (Assistant Production Manager I) and action is taken to include this methodology as a SOP for the Glazing Lines.

\section{Project Results}

Yield, production and cost savings for the year 2015 given on a monthly basis are shown in Table 15.

Table 15: Yield Improvement and Cost Savings for 2015

\begin{tabular}{|c|c|c|c|c|c|c|c|}
\hline Month & $\begin{array}{c}\text { Average Reject } \\
\text { Yield \% } \\
\text { (Before } \\
\text { implementation) } \\
\text { (May to October } \\
\text { 2014) }\end{array}$ & $\begin{array}{c}\text { Average Reject } \\
\text { Yield \% } \\
\text { (After } \\
\text { implementation) }\end{array}$ & $\begin{array}{c}\text { Yield } \\
\text { improvement } \\
\%\end{array}$ & $\begin{array}{l}\text { Total monthly } \\
\text { production } \\
\text { (sq.m) }\end{array}$ & $\begin{array}{l}\text { Total monthly } \\
\text { savings (sq.m) }\end{array}$ & $\begin{array}{l}\text { Average cost/ } \\
\text { sq.m LKR } \\
\text { (Jan 2015) }\end{array}$ & $\begin{array}{l}\text { Tot savings } \\
\text { LKR. }\end{array}$ \\
\hline Jan-15 & 8.86 & 5.53 & 3.33 & 132,653 & 4,417 & 754.42 & $3,332,533.34$ \\
\hline Feb-15 & 8.86 & 5.59 & 3.27 & 122,749 & 4,014 & 725.16 & $2,910,714.14$ \\
\hline Mar-15 & 8.86 & 6.01 & 2.85 & 134,246 & 3,826 & 740.01 & $2,831,286.40$ \\
\hline Apr-15 & 8.86 & 10.28 & -1.42 & 34,757 & 0 & 1369.39 & - \\
\hline May-15 & 8.86 & 7.28 & 1.58 & 93,307 & 1,474 & 824.39 & $1,215,357.45$ \\
\hline Jun-15 & 8.86 & 5.99 & 2.87 & 130,369 & 3,742 & 723.79 & $2,708,125.64$ \\
\hline Jul-15 & 8.86 & 5.21 & 3.65 & 138,389 & 5,051 & 657.97 & $3,323,537.08$ \\
\hline Aug-15 & 8.86 & 5.75 & 3.11 & 150,570 & 4,683 & 638.76 & $2,991,138.70$ \\
\hline Sep-15 & 8.86 & 6.36 & 2.5 & 139,791 & 3,495 & 667.94 & $2,334,300.01$ \\
\hline Oct-15 & 8.86 & 5.00 & 3.86 & 133,749 & 5,163 & 632.38 & $3,264,795.44$ \\
\hline Nov-15 & 8.86 & 5.69 & 3.17 & 135,616 & 4,299 & 714.13 & $3,070,064.29$ \\
\hline Dec-15 & 8.86 & 5.56 & 3.30 & 148,903 & 4,914 & 746.19 & $3,666,627.68$ \\
\hline \multicolumn{7}{|c|}{ Total savings for the year 2015} & $31,648,480.17$ \\
\hline \multicolumn{7}{|c|}{ Total Saving for the year 2015 (LKR.) } & $31,648,480.17$ \\
\hline \multicolumn{7}{|c|}{ Average Saving per month (LKR.) } & $2,637,373.34$ \\
\hline
\end{tabular}

Note: The reason for the negative improvement in the month of April 2015, was the stoppage of the plant for annual maintenance for 22 days.

\section{Key Learning Points}

The lessons learnt through the implementation of the project are manifold. It revealed that methodical and systematic application of the Six Sigma system using the thinking process of DMAIC enabled the team to identify sources of variations which had gone undetected for a 
long period of time. The following are the key lessons learnt which are worth recording for further reference and studies.

i. The importance of analyzing the data sourced from live tests without analyzing the historical data (secondary data)

ii. The importance of analyzing the complete system without attacking each defect individually as there are correlations among defects.

iii. Using Control Charts in the Glazing Lines and explaining to the operatives daily has improved the control of "situational type defects".

iv. Successful implementation of the project with the support of employees who are directly involved lead to a change in the attitude of employees to make use of data as a source of knowledge. Low cost, simple factory-born ideas were implemented by operators with the support of managers leading to respecting the knowledge workers and cooperating with them to achieve other goals of the factory as well.

v. Top management has realized the importance of the Six Sigma system and heavily invested in efforts at knowledge improvement of the employees of the entire company.

vi. There is a huge potential in the industry for Six Sigma application, if the right project and the right team are selected.

\section{Conclusion}

The study was initiated with the aim of reducing glazing defects by improving the stability and capability of the production process. It revealed that the faithful application of the DMAIC cycle was the key to producing tangible results. Further, it showed that the collection and analysis of critical data with the correct statistical tools play a vital role in creating simple but profitable solutions for the problem being investigated. Moreover, the team who managed the study played a productive role without which the results could not have been reached. Hence it is recommended that the application of Six Sigma methodology be expanded to other major processes in production as well as in services to streamline the business. Six Sigma methodologies have produced not only sustainable results in the bottom-line of many firms in Sri Lanka but have also produced Six Sigma professionals, who will take up the real challenge posed by the global business environment. In order to refine the process of Six Sigma implementation, a further study of Six Sigma methodology is recommended especially in areas such as the assessment of cost of poor quality (COPQ), rolled throughput yield, process capability index and use of control charts to stabilize the process. 


\section{NSBM Journal of Management}

Vol. 1, No. 2, July-December, 2015

\section{References}

Barney, M 2002, ‘Motorola's second generation', Six Sigma Forum Magazine, vol. 1, no. 3, pp. 13-16.

Blakeslee, JA 1999, 'Implementing the Six Sigma solution: how to achieve quantum leaps in quality and competitiveness', Quality Progress, vol. 32, no. 7, pp. 77-85.

Brady, JE \& Allen, TT 2006, 'Six Sigma literature: a review and agenda for future research', Quality and Reliability Engineering International, vol. 22, no. 3, pp. 335-367.

Chakrabarty, A \& Tan, KC 2007, 'The current state of Six Sigma application in services', Managing Service Quality, vol. 17, no. 2, pp. 194-208.

Choo, AS, Linderman, KW \& Schroeder, RG 2007, 'Method and context perspectives on learning and knowledge creation in quality management', Journal of Operations Management, vol. 25, no. 4, pp. 918-931.

Chalapathi, RS 2005 a, DMAIC plus, art \& science of Sig Sigma problem solving, $1^{\text {st }}$ edition, Institute of Sigma Learning (Pvt.) Ltd., Ghaziabad, pp. 1-55.

Chalapathi, RS 2005 b, Developing Six Sigma competencies, first edition, Institute of Sigma Learning (Pvt.) Ltd., Ghaziabad, pp. 23-55.

Chalapathi , RS 2005 c, Six Sigma tool master: a practical guide to Green Belts and Black Belt, $1^{\text {st }}$ edition, Institute of Sigma Learning (Pvt.) Ltd., Ghaziabad, , pp. 17-59.

Coronado, RB \& Antony, J 2002, 'Critical success factors for the successful implementation of Six Sigma projects in organizations', The TQM Magazine, vol. 14, no. 2, pp. 92-99.

Goh, TN 2002, 'A strategic assessment of Six Sigma', Quality and Reliability Engineering International, vol. 18 no. 5 , pp. 403-410.

Hahn, GJ, Doganaksoy, N \& Hoerl, R 2000, 'The evolution of Six Sigma', Quality Engineering, vol. 12 , no. 3, pp. 317-326.

Harry, MJ \& Schroeder, R 2000, Six Sigma: The breakthrough management strategy revolutionizing the world's top corporations, Currency, New York, NY.

Linderman, K, Schroeder, RG, Zaheer, S \& Choo, AS 2003, 'Six Sigma: a goal-theoretic perspective', Journal of Operations Management, vol. 21 no. 2, pp. 193-203.

Schroeder, RG, Linderman, Liedtke, C. \& Choo, AS 2008, 'Six Sigma: definition and underlying theory', Journal of Operations Management, vol. 26 no. 4, pp. 536-554.

Sung Park, H, 'Six Sigma for quality and productivity promotion', Asian Productivity Organization, Productivity Series, vol. 32, pp 35-37.

$\mathrm{Zu}, \mathrm{X}$, Fredendall, LD and Douglas, TJ 2008, 'The evolving theory of quality management: the role of Six Sigma’, Journal of Operations Management, vol. 26, no. 5, pp. 630-650. 